AGRO EKONOMI, Vol 29, No 1, Juni 2018, Hal.132-145

DOI : http://doi.org/ 10.22146/ae.34835

ISSN 0215-8787 (print), ISSN 2541-1616 (online)

Tersedia online di https://jurnal.ugm.ac.id/jae/

\title{
THE IMPACT OF MECHANIZATION UNDER UPJA PROGRAM ON RICE FARMING INCOME IN PRAMBANAN SUB-DISTRICT SLEMAN DISTRICT
}

\section{Dampak Mekanisasi Melalui Program UPJA Terhadap Pendapatan Usahatani Padi di Kecamatan Prambanan Kabupaten Sleman}

\author{
Kurnia Arif Oktovianto ${ }^{1}$, Irham ${ }^{2}$, Suhatmini Hardyastuti ${ }^{3}$ \\ ${ }^{1}$ Master Students of Agribusiness Management Faculty of Agriculture, \\ Universitas Gadjah Mada \\ ${ }^{2,3}$ Faculty of Agriculture, Universitas Gadjah Mada \\ Jl. Flora No. 1 Bulaksumur, Yogyakarta \\ arifokto05@gmail.com
}

\begin{abstract}
The Agricultural machinery rental services (UPJA) program has an important role on the application of agricultural mechanization and increasing farming income. This study aims: (1) to compare the farm costs between the farmers who apply mechanization under UPJA program and those who do not (Non-UPJA), and (2) to know the effect of implementing agricultural mechanization and the other factors toward farm income in Prambanan SubDistrict, Sleman District. The data collected consists of 25 farmers who apply agricultural mechanization under UPJA program, choosen by sensus and 25 farmers who do not apply (Non-UPJA), choosen by using proporsional random sampling. To determine the differences of farm costs, farming analysis and mean difference test using independent sample t-test was applied. To determine the effect of mechanization toward farm income, multiple liniear regression analysis was used. The result of mean difference test showed that there is no significant differences of farm costs between UPJA and Non-UPJA farmers. The result of multiple liniear regression analysis showed that mechanization has significant effect to the farm income. Farm income of the farmers who apply mechanization under UPJA program is significantly higher than the farmers who do not. Other factors that have significant effect to farm income are land area, price of organic fertilizer and price of ZA fertilizer.
\end{abstract}

Keyword: farming, mechanization, multiple liniear regression.

\section{INTISARI}

Program UPJA (Usaha Pelayanan Jasa Alsintan) mempunyai peranan penting dalam upaya penerapan mekanisasi pertanian dan peningkatan pendapatan usahatani. Penelitian ini bertujuan untuk: (1) membandingkan biaya usahatani antara petani yang menerapkan mekanisasi melalui program UPJA dengan petani yang tidak menerapkan (Non-UPJA), dan (2) mengetahui dampak dari penerapan mekanisasi dan beberapa faktor lain terhadap pendapatan usahatani di Kecamatan Prambanan Kabupaten Sleman. Data yang dikumpulkan adalah dari 25 responden petani yang menerapkan mekanisasi melalui program UPJA secara sensus, dan 25 responden petani yang tidak menerapkan (Non-UPJA) secara proporsional random sampling. Untuk membandingkan biaya usahatani digunakan analisis usahatani yang selanjutnya diuji beda rata-rata dengan independent simple t-test. Untuk 
mengetahui dampak mekanisasi terhadap pendapatan usahatani digunakan analisis regresi linier berganda. Hasil uji beda rata-rata menunjukkan bahwa tidak terdapat perbedaan signifikan pada biaya usahatani antara petani UPJA dan petani Non-UPJA. Hasil dari analisis regresi linier berganda menunjukkan bahwa mekanisasi berpengaruh signifikan terhadap pendapatan usahatani. Pendapatan Usahatani yang menerapkan mekanisasi melalui program UPJA secara signifikan lebih besar daripada yang tidak menerapkan. Faktor lain yang juga berpengaruh signifikan terhadap pendapatan usahatani adalah luas lahan, harga pupuk organik dan harga pupuk ZA.

Kata Kunci: mekanisasi, regresi linier berganda, usahatani.

\section{INTRODUCTION}

Agricultural mechanization is a technology which can reduce labor use (Suratiyah, 2010). Agricultural mechanization plays a role not only in increasing wide arable and intensity of plant, but also increasing the farm productivity and efficiency, pushing lost of yields and increasing the quality of agricultural product, as well as expanding employment opportunity in rural by creating intregrated agribusiness system that will spur rural economic growth (Djamhari, 2009). The development of an independent agricultural industry in rural with the support from agricultual mechanization technology can realize efficient, competitive, and sustainable agricultural industry. Agricultural mechanization is based on the enhancment of farmer and agribusiness income (Umar, 2014).

Agricultural mechanization can support the production so that it can increase work efficiency, planting intensity, plant quality and quantity, efficiency, product diversification and value (Handaka \& Prabowo, 2013). An increase in work productivity can be achieved through work capacity enhancement and time savings to soil processing, planting, maintenance, post-harvest, and product processing. Mechanization is done not only for production, but also for overcoming man power decrease in agriculture especially on farm field (Loesasi, 2013). To achieve high farming efficiency, the use of mechanization should be adjusted with the land area and the kind of plant (Takeshima, Nin-Pratt, \& Diao, 2013).

In realizing superior agriculture and prosperous farmers, it is necessary to have key actors and business actors that qualified, reliable, capable of managerial, entrepreneurial, and business organizations. Such capacity and capabilities can be enhanced through counseling and farmer group approaches. The group approach in counseling is intended to improve the effectiveness and efficiency of the expansion organization. It is also intended to encourage the growth of farmer 
institutions (farmer groups, farmer group associations). Through farmer groups, extension activities and training in a more organized can be done to build synergy among farmers in achieving business efficiency (Handaka \& Prabowo, 2013).

The utilization of agricultural machinery in the field is done by the UPJA (agricultural machinery rental services). The program aims to increase farmers income by increasing food production through planting area extensions, increasing plant indices, reducing possible yield losses, and overcoming the scarcity of agricultural machinery in farming communities. Under UPJA program, farmers not only use agricultural machinery but are also taught to farm efficiently in the use of inputs (Hanggana, 2018).

UPJA is a rural economic institution engaged in service in order to optimize the use of agricultural machinery to obtain business profits, where UPJA implementers are farmer groups. UPJA is expected to be able to supply agricultural machinery for farmers and provide benefits for farmers by reducing farming costs. The development of agricultural machinery in order to utilize innovation and technology of agricultural mechanization through UPJA for considering: (1) farmer's ability in cultivating farming land is limited, (2) managerial of agricultural machine is less efficient, (3) the level of farmers education and skill is low, (4) capital capability of the farm is weak, and (5) management of farming system is inefficient (Hanggana, 2018).

The UPJA program that aimed to reduce farming costs is not always successful. In some cases there are problems such as the agricultural machinery which do not meet the needs of farmer group members, consequently other farmers have to hire the services to the market whose price is more expensive. Therefore, in order to avoid disputes among members of farmer groups, the rental price in UPJA is equated with the rental price in the market (Hanggana, 2018). UPJA is a professionally managed institution established by farmers as partners of farmer groups and farmer groups association with the purpose of obtaining profit. This causes the rental price of agricultural machinery services cannot be minimized.

UPJA is located in the Prambanan Sub-District, Sleman District named UPJA Sumber Makmur. Agricultural machinery owned by UPJA Sumber Makmur include 4 wheel and 2 wheel tractor, rice tranplanter, water pump, and combine harvester. The agricultural machineries which are often utilized are tractor for soil processing, rice tranplanter for planting and combine harvester for harvest.

The formulation problem of this research paper focuses on the difference of farm costs between the farmers who apply mechanization under UPJA program 
and the farmers who do not apply (NonUPJA); as well as the impact of agricultural mechanization under UPJA program on farm income in Prambanan Sub-District, Sleman District. After formulating the problem, furthermore it can be seen the purpose of this research paper which is to compare the farm costs between the farmers who apply mechanization under UPJA program and those who do not, and to know the impact of mechanization and the other factors on farm income.

\section{METHOD}

\section{Location \& Data}

The location of the study was determined by purposive method. This research was conducted in Prambanan Sub-District, Sleman District. The time of the research is in November until December 2017. The data is taken of farming season in 2017 (May to August). The determination of sample location of this research was conducted by considering: (1) the existence of complete agricultural equipment and machinery (tractor, rice transplanter and combine harvester) from government aid through UPJA institution, (2) The UPJA is operated by farmer groups association for modern agriculture pilot in Yogyakarta Province. The data collected consist of primary data and secondary data. Primary data was obtained by interviewing the rice farmers in Prambanan Sub-district.
The number of respondents is 50 farmers where 25 farmers are farmers who apply mechanization under UPJA program, taken by census and 25 farmers who are comparative farmers who do not apply (non-UPJA) taken by using proportional random sampling.

\section{Data analysis}

Farm cost is expenses that sacrificed by the farmers for farming, with the aim of benefiting from the farm. Cost components incurred by farmers include the cost of production facilities, labor, mechanization's service and land rent or sharecrop that directly affect the income.

Farm income in this study is the difference between farm revenue and the cost of rice farming. The formula is as follows (Suratiyah, 2008):

$$
\begin{aligned}
& \mathrm{NR}=\mathrm{TR}-\mathrm{TC}_{\text {explicit }} \\
& \mathrm{TR}=\text { Py.y }
\end{aligned}
$$

Information:

$\mathrm{NR}=$ Farm income (IDR)

$\mathrm{TR}=$ Total revenue earned from farming (IDR)

Py = Price per unit (IDR / kg)

$\mathrm{y} \quad=$ Total production $(\mathrm{kg})$

$\mathrm{TC}=$ Total cost incurred from farming (IDR)

\section{Hypothesis Testing}

To draw the conclusions, independent sample $t$ test is used. The Hypothesis as follow: 


$$
\begin{array}{ll}
\mathrm{H}_{0} & : \mu_{1}=\mu_{2} \\
\mathrm{H}_{1} & : \mu_{1} \neq \mu_{2}
\end{array}
$$

The formulation of $\mathrm{t}$ stat as follow:

$$
\text { t stat }=\frac{X 1-X 2}{\sqrt{\frac{(n 1-1) s 12+(n 2-1) s 12}{n 1+n 2-2}\left(\frac{1}{n_{1}}+\frac{1}{n_{2}}\right)}}
$$

Decision making is: If $\operatorname{sig} \mathrm{t}<0.05$, then $\mathrm{H}_{0}$ is rejected, whereas If sig $\mathrm{t} \geq$ 0.05 , then $\mathrm{H}_{0}$ accepted. If $\mathrm{t}$ stat positive, than farm costs of the farmers who apply mechanization under UPJA program is significantly higher than the farmers who do not apply (non-UPJA), whereas if the $t$ stat is negative than the farm costs of farmers who apply mechanization under UPJA program is significantly lower than the farmers who do not apply (non-UPJA).

To find the effect of mechanization on farm income, multiple regression analysis was used by Ordinary Least Square (OLS) method. The model used is Cobb-Douglass income function as follows:

$$
\begin{aligned}
\text { Ln NR }= & \text { Ln } \beta_{0}+\beta_{1} \text { LnHBT }+\beta_{2} \text { LnUTK } \\
& +\beta_{3} \text { LnHPU }+\beta 4 \text { LnHPP }+ \\
& \beta_{5} \text { LnHPO }+\beta_{6} \text { Ln HPZ }+ \\
& \beta_{7} \text { LnHPs }+\beta_{8} \text { LnLL }+\beta_{9} \mathrm{D}+\mu
\end{aligned}
$$

Where;

$\mathrm{NR}=$ farm income is normalized

$\beta_{0}=$ value of constant

$\beta_{\mathrm{i}} \quad=$ regression coefficient

$\mathrm{HBT}=$ price of seed is normalized
$\mathrm{UTK}=$ price of labor is normalized

$\mathrm{HPU}=$ price of urea fertilizer is normalized HPP $=$ price of ponska fertilizer is normalized

$$
\mathrm{HPO}=\text { price of organic fertilizer is }
$$
normalized

$\mathrm{HPZ}=$ price of $\mathrm{Za}$ fertilizer is normalized HPs $=$ price of pesticide is normalized

$\mathrm{LL}=$ land area $\left(\mathrm{m}^{2}\right)$

$\mathrm{D}$ =dummy mechanization, $1=$ mechanization, $0=$ manual

$\mu \quad=$ error or nuisance variable

\section{RESULTS AND DISCUSSION}

\section{The comparison of farm inputs}

The inputs used in rice farming such as production facilities and labor. Production facilities include seeds, fertilizers, and pesticide while labor includes soil processing, planting, maintenance, and harvesting.

From Table 1, it can be seen that there are differences in the quantity of inputs used by UPJA and non-UPJA farmers. In the use of seeds, the application of mechanization requires more seeds. This is due to the technical requirements of the rice transplanter machine that requires the seeds to have thick clumps so that when-planting is done, emptiness seeds implanted does not occur. In the farmers who apply UPJA program, the use of chemical fertilizers such as urea, ponska, and $\mathrm{ZA}$, is minimized while the use of organic fertilizers is greatly maximized, 
Tabel 1. The comparison of farm inputs per $1000 \mathrm{~m}^{2}$.

\begin{tabular}{lrrr}
\hline Input & Under UPJA & Non-UPJA & t stat \\
\hline Seeds $(\mathrm{kg})$ & 6.47 & 5.39 & $3.247^{* * *}$ \\
Urea fertilizer $(\mathrm{kg})$ & 28.50 & 38.50 & $-1.675 \mathrm{~ns}$ \\
Ponska fertilizer $(\mathrm{kg})$ & 37.58 & 37.04 & $0,089 \mathrm{~ns}$ \\
ZA fertilizer $(\mathrm{kg})$ & 21.25 & 32.92 & $-1.321 \mathrm{~ns}$ \\
Organic fertilizer (kg) & 514.80 & 213.33 & $4.617^{* * *}$ \\
Pesticide (liter) & 0.04 & 0.06 & $-2.261^{* *}$ \\
Labor (HKO) & 3.91 & 9.06 & $-93.409 * *$ \\
Machine (HKM) & 8.81 & 5.02 & $65.78^{* * *}$ \\
\hline
\end{tabular}

Source: Primary data Analysis, 2017

Information:

$* * * \quad=$ significant at $\alpha=1 \%$

$* * \quad=$ significant at $\alpha=5 \%$

ns $=$ not significant

because in UPJA program agricultural extension workers not only provide lessons on agricultural mechanization, but also provide suggestions for reducing the use of chemical fertilizers. The reduction of chemical fertilizer is expected to restore soil fertility so that the productivity can increase. However, the use of ponska fertilizer by UPJA farmers is still high. It is because the farmers still consider that the ponska fertilizer greatly affects the production.

The results of the analysis in Table 1 indicate that the average use of chemical fertilizers (Urea and ZA) by UPJA farmers is lower non-UPJA farmers. However, the value of $t$ stat shows that there is no significant difference in the use of urea, ponska, and ZA fertilizers between UPJA and non-UPJA farmers. In terms of pesticides usage, the value of $t$ stat is negative, meaning that the use of pesticides by UPJA farmers is significantly lower than non-UPJA farmers.

The use of organic fertilizer is greatly maximized by UPJA farmers. From the results of $t$ stat can be concluded that the use of organic fertilizer by UPJA farmers is significantly higher than non-UPJA farmers. The application of mechanization can reduce labor as shown in Table 1 . In planting work, the labor required for planting by manual means more than mechanization. By using manual way, a land area of $1000 \mathrm{~m}^{2}$ can takes planting labors of 7-8 female with 2-3 hours while mechanization takes 2 men labor plus planting machine which takes $45-60$ minutes.

In harvest work, the labor required to harvest rice area of $1000 \mathrm{~m}^{2}$ by mechanization is 2 persons where one person is the driver and another one is the collector of the results. The time required 
ranges from 30 minutes to 60 minutes depends on the state of the soil and plants. Harvest by manual way requires 3-5 people to work with 4-5 hours. The manual harvesting is very susceptible to the loss of weight.

\section{The comparison of farm costs}

Based on the farming analysis at table 2 , it can be seen the structure of farming cost (explicit) from: (1) 25 farmers who apply the mechanization under UPJA program and (2) 25 farmers who do not apply (non-UPJA). Costs are sacrifices or expenses that sacrificed by the farmers for farming, with the aim of benefiting from the farm. From the total cost of farming there is a difference between UPJA and Non-UPJA farmers. Total cost of UPJA farmers is higher than non-UPJA farmers.

From the difference of farming cost, the big difference occurrs in planting, fertilization, harvesting, and land rent or sharecrop (revenue share with landowner), while at the other cost is relatively similar. The average Cost of rice planting when the farmers are applying mechanization under UPJA program is IDR 314,405.24 per 1000 $\mathrm{m}^{2}$ while the farmers who apply the manual way is IDR $214,881.50$ per $1000 \mathrm{~m}^{2}$.

The planting costs when farmers apply mechanization under UPJA program is more expensive than when manual planting (non UPJA). In this case, the cost of planting is the overall cost from nursery until planting. When using mechanization, farmers do not need to nursery because from the nursery until planted, have been done by UPJA using rice transplanter machine. While in the manual planting, only the planting done by planting labour. The work of purchasing seeds, seedlings, and other are done by the farmers themselves.

The results of interviews with farmers, the application of rice transplanter machine under UPJA program very useful for planting activities. At the time of planting season, existing planting labor cannot guarantee the timeliness of planting because the land is larger than the existing planting labor capacity so farmers have to wait their turn for the land to be planted. The length of waiting time for planting ranges from 10 days to 20 days. After the aid of rice transplanter under UPJA program, farmers are easier to determine the planting schedule because starting from the nursery until planting has been done by UPJA. The time required for the nursery is $15-20$ days after scattering so that farmers can order on a planned date. From the interview with farmers, there are several advantages and weakness of rice transplanter machine. The advantages of these machines are:

1. Improving timeliness of planting, so farmers can plan for planting from afar.

2. Reduce side jobs in planting activities such as nurseries, spraying that require more labor. For large cultivated land, 
this side job requires labor costs that will increase farming costs.

While the weaknesses of rice transplanter machine are:

1. The price is more expensive if the cultivated rice field is not too large because in addition to lease of planting services, also have to spend transportation costs from UPJA to the land so that farmers prefer to do the planting manually because labor costs for manual planting is lower than the cost of planting services rental while the job sideline can be done alone.

2. The cropping done by the machine is not as trivial as the result of manual labor. Often when using planting machine is not straight line and often happens empty planting where the machine is not planted at certain moments so it must be done patchwork.
3. Requires more seeds than manual cropping. If with manual planting the use of seeds is recommended only 2 $\mathrm{kg}-3 \mathrm{~kg}$, whereas when using the machine required seeds as much as 6 $\mathrm{kg}-7 \mathrm{~kg}$.

A big difference is also shown in fertilizer work where the farmers who apply UPJA program issue spend higher average cost than non-UPJA farmers which the difference reaches IDR 122,519,09. Farmers who apply UPJA program tend to incur higher costs for the purchase of organic fertilizers and minimize the use of chemical fertilizers.

At harvest work, mechanization method using a combine harvester machine also increases the costs. Table 2 shows that the application of mechanization is more expensive than the manual. The wage system of mechanization application is IDR $250,000.00$ per $1000 \mathrm{~m}^{2}$ or bawon

Table 2. The comparison of average farming costs per $1000 \mathrm{~m}^{2}$.

\begin{tabular}{lrrr}
\hline Costs & Under UPJA (IDR) & Non UPJA (IDR) & differences (IDR) \\
\hline Soil processing & $132,133.33$ & $144,109.45$ & $11,976.12$ \\
Planting & $314,405.24$ & $214,881.50$ & $99,523.74$ \\
Fertilization & $455,851.98$ & $333,332.89$ & $122,519.09$ \\
Pesticide & $13,694.05$ & $18,083.43$ & $4,389.38$ \\
Harvesters & $251,237.62$ & $216,485.91$ & $34,751.71$ \\
Maintenance & $25,416.67$ & - & $25,416.67$ \\
Depreciation & $15,754.71$ & $21,012.85$ & $5,258.14$ \\
Rent land/sharecrop & $85,385.14$ & $191,862.85$ & $106,477.71$ \\
\hline Total costs & $\mathbf{1 , 2 7 4 , 5 6 2 . 0 6}$ & $\mathbf{1 , 1 3 9 , 7 6 8 . 2 2}$ & $\mathbf{1 3 4 , 7 9 3 . 8 4}$ \\
\hline
\end{tabular}

Source : Primary data Analysis, 2017 
is $1: 10$, while in manual harvest using gebot or pedal thresher, the labor wage is bawon of 1: 7 to 1:8. Bawon is the wage given to harvest labor in the form of rice. For example if it is $1: 8$, then from 8 sacks rice, the harvest labor acquires 1 sack of rice.

From the results of interviews with farmers, there are several advantages and weakness of combine harvester machine. The advantages of these machines are:

1. The requirement time for harvesting is so short that farmers can receive the income faster.

2. The machine can decrease loss of rice (losses), so can produce more. In addition, the result is clean rice.

3. The cost of harvest does not depend on the productivity of paddy produced so that farmers can estimate their income. This is very advantageous if the rice productivity is high.

While the weaknesses of combine harvester are:

1. This machine is large and heavy so not all the land can applied. When harvesting, the land should be dry so that the wheels can run while during rainy season this machine is very rarely used.

2. The unavailable of farm roads to reach the land in the middle of rice fields so it is very difficult to apply this harvest machine.
The last costs that have a large enough difference are the rent land and sharecrop. In farm which applies UPJA program, the cultivated land is largely self-owned and rented, while the farmers who non-UPJA of the cultivated land are self-owned and sharecrop. Land rent in the study sites ranged from IDR 750 - 800 per $\mathrm{m}^{2}$ per year while for sharecrop, the sharing between farmer and landowner is the rice ranged from $40-45 \%$. This rice sharing is very burdensome to the farmers because all the costs of production facilities issued by the farmers.

To find out whether there are significant differences in soil processing costs, planting costs, harvest costs, and farming costs between UPJA and nonUPJA farmers is using independent sample t-test.

From the result of independent sample t-test at table 3, showed that the significance value at cost of soil processing is $0.184(>0.05)$. This indicates that $\mathrm{H}_{0}$ is accepted and $\mathrm{H}_{1}$ is rejected, and the conclusion is that there is no significant difference in cost of soil processing between UPJA and non-UPJA farmers.

There was no significant difference in the price of soil processing using tractor machine either under UPJA program or non-UPJA. Supposedly, the UPJA program can minimize costs because the tractor machine is a relief from the government. According to Hanggana (2018), the tractor 
rental price under UPJA is not different from the rental price in the market because UPJA's agricultural machinery is not enough to meet the needs of the members of farmers group, so to avoid friction between farmers, UPJA set the same rental price with market price.

The result of independent sample t-test analysis in Table 3 shows that the significance value at planting cost is $0.000(<0.05)$, therefore $\mathrm{H}_{0}$ is rejected and $\mathrm{H}_{1}$ accepted, it means that there are significant differences. Planting cost using mechanization under UPJA program is significantly higher than the manual one (non-UPJA). Significant differences are also found in harvest costs. This result is different from the research conducted by Harnel, (2012), who state that the application of planting mechanization reduces the cost of farming in Sijunjung District, West Sumatra, where the average cost of planting equipment is $325,057 /$ ha while the manual is IDR $653,343 /$ ha.

The result of independent sample t-test at harvest costs shows the significance value of $0.001(<0.05)$, therefore $H_{0}$ is rejected and $\mathrm{H}_{1}$ accepted, it means that there are significant differences. Harvest cost using mechanization under UPJA program is significantly higher than the manual way (non-UPJA). Next is the analysis on farm costs. From the result of independent sample t-test, the significance value at total cost of farming is 0.059 (>
0.05). This indicates that $\mathrm{H}_{0}$ is accepted and $\mathrm{H}_{1}$ is rejected, and the conclusion is that there is no significant difference in farm costs between UPJA and non-UPJA farmers.

\section{The comparison of farm income}

In addition to comparing farm costs, this study also compared the farm income. Farming income is net revenue that can be generated by the farmers in the activities of farming. Farm income is known by calculating the difference between revenue and farming costs (explicit). The comparison of farm income is showed in table 4.

Table 4 illustrates the comparison of farm income between (1) 25 farmers who apply mechanization under UPJA program and (2) 25 farmers who do not applying (non-UPJA). From the farming income analysis that is shown in table 4, it can be seen that farming income from farmers who apply mechanization under UPJA program is much higher than the farmers who do not applying (non-UPJA). This is in line with research conducted by Widiastuti (2014), where farming incomes that the farmers who apply full mechanization under UPJA program in Kalikotes Sub-District, Klaten District is higher than the farmer who apply partial mechanization. In addition, the analysis shows that there is an increase of farmer incomes after the UPJA program. 
Table 3. The result of independent sample t-test.

\begin{tabular}{lrrrr}
\hline Costs & Under UPJA & Non UPJA & t-stat & Sig \\
\hline Soil processing & $132,133.33$ & $144,109.45$ & -1.349 & 0.184 \\
Planting & 314405.24 & 214881.50 & 7.259 & 0.000 \\
Harvesting & 251237.56 & 216.485 .91 & 3.533 & 0.001 \\
Total costs & 1274562.06 & 1139768.22 & 1.931 & 0.059 \\
\hline
\end{tabular}

Source : Primary data Analysis, 2017

The difference of farm income is caused by the farmers who apply UPJA program is the farmer who intensive farming starting from the processing of soil, fertilization, maintenance, until the harvest. Most farmers who use mechanization under UPJA program have applied modern agriculture where the farm is intended for commercial purposes. It can be seen that the productivity from the farmers who apply mechanization is higher than who do not apply (non-UPJA).

\section{The Effect of mechanization on farm income}

To find out whether there is a significant influence from the application of mechanization to the income of rice farming, multiple linear regression analysis is used. Multiple linear regression analysis was conducted to find out the correlation between dependent variable with more than one independent variable. This model has passed the classical assumption test that is normality, multicollinearity, and heteroscedasticity test.

The result of multiple linear regression analysis in table 5 shows that variable of land area, price of organic fertilizer, price of ZA fertilizer, and mechanization have significant effect to farm income, while other variable that is price of urea fertilizer, price of ponska fertilizer, and price of pesticide have no significant effect.

Land area has a coefficient of 1.508 with a significance value of 0.000 which means less than 0.01 or $99 \%$ confidence level. This shows that the land area has a significant effect on farm income. Coefficient has a positive value which means land area and rice farming income has positive correlation. If the land area increased by $1 \%$ it will increase the rice production by $1.508 \%$. This is due to the larger land area, the more plants that can be planted so that it will increase the income of farming. This result is in line with the research of Kusnadi, Tinaprilla, Susilowati, \& Purwoto (2011), that the land area has a significant effect on rice production in five provinces of rice producing center that are North Sumatra, West Java, Central Java, East Java, and South Sulawesi. Increased rice production will also increase rice revenues.

The price of organic fertilizer has a significant coefficient of 0.177 at a $95 \%$ 
Table 4. The comparison of average farming income per $1000 \mathrm{~m}^{2}$.

\begin{tabular}{lcc}
\hline Description & Under UPJA & Non UPJA \\
\hline Productivity $\left(\mathrm{kg} / 1000 \mathrm{~m}^{2}\right)$ & 553.51 & 397.67 \\
Farm revenue (IDR) & $2,510,190.29$ & $1,731,887.30$ \\
Farming Costs (IDR) & $1,274,562.06$ & $1,139,768.22$ \\
Farming income (IDR) & $\mathbf{1 , 2 3 5 , 6 2 8 . 2 2}$ & $\mathbf{5 9 2 , 1 1 9 . 0 8}$ \\
\hline
\end{tabular}

Source: Primary data Analysis, 2017

Table 5. The results of multiple linear regression analysis.

\begin{tabular}{lcr}
\hline variable & coefficient & $\mathrm{t}$ stat \\
\hline Constant & $3.586 * * *$ & 3.401 \\
Land area $\left(\mathrm{m}^{2}\right)$ & $1.508 * * *$ & 7.175 \\
Price of urea fertilizer is normalized & $-0.130 \mathrm{~ns}$ & -0.757 \\
Price of phonska fertilizer is normalized & $-0.230 \mathrm{~ns}$ & -1.364 \\
Price of organic fertilizer is normalized & $0.177 * *$ & 2.112 \\
Price of ZA fertilizer is normalized & $-0.129 * *$ & -2.611 \\
Prices of pesticides are normalized & $0.110 \mathrm{~ns}$ & -0.744 \\
Dummy mechanization & $0.387 * *$ & 2.293 \\
\hline $\mathrm{F}$ & $36.289 * * *$ \\
Adjusted $\mathrm{R}^{2}$ & 0.834 & \\
\hline
\end{tabular}

Source : Primary data Analysis, 2017

Information:

$* * * \alpha=1 \%(\mathrm{t}$ table $=2.685)$

$* * \alpha=5 \%(\mathrm{t}$ table $=2.017)$

ns $=$ not significant

confidence level. This shows that the price of organic fertilizer has a significant effect on farm income. The coefficient has a positive value which means that the price of organic fertilizer and farm income have positive correlation. If the price of organic fertilizer increased by $1 \%$ it will increase the income of farming by $0.177 \%$. The higher the price of organic fertilizer indicates that the use of organic fertilizer is also higher. The use of organic fertilizer is very influential on rice production which further affects the income of farming. This results are in line with Fitriyani \& Bangun (2014), that Organic SRI training programs in which inputs such as seeds and fertilizers are organic products, conducted by PT Medco E \& P Indonesia have a positive impact on farmer income and increase rice productivity in Parit 9 Sub-District Banyuasin, South Sumatra.

The use of organic fertilizer can improve soil fertility. It is proved by Padmanabha, Arthagama, \& Dibia (2014), that organic fertilizers give an increase of $\mathrm{N}$-total and C-organic soil, where if these two elements are higher, so the soil fertility 
is higher too. Increased soil fertility will increase productivity and farm income.

The Price of ZA fertilizer has a significant coefficient of -0.129 at $95 \%$ confidence level. This indicates that the price ofZA fertilizer has a significant effect on farm income. The coefficient of negative value means the price of ZA fertilizer and farm income has a negative relationship where if there is an increase of ZA fertilizer price by $1 \%$, it will reduce farm income by $0.129 \%$.

Dummy mechanization has a significant at a $95 \%$ confidence level, which means that mechanization has a significant effect and has a positive correlation on farm income. Farm income of the farmers who apply mechanization under UPJA program is significantly greater than the farmers who do not apply (non-UPJA).

\section{CONCLUSION AND SUGGESTION}

Based on the results of research and analysis that have been done, it can be concluded that there is no significant difference in total farming costs. In addition, the application of mechanization has a significant effect on farm income. Farm income of the farmers who apply mechanization under UPJA program is significantly higher than the farmers who do not apply (non-UPJA). Other factors that significantly influence farm income in Prambanan Sub-District, Sleman District are the land area, price of organic fertilizer and the price of ZA fertilizer.
The implementation of mechanization is not profitable if the land is narrow. It is necessary to cooperate with several farmers who have adjacent land for planting and harvesting simultaneously. The analysis shows that the price of organic fertilizer has a significant effect and positive correlation on farm income. Therefore, farmers are expected to increase the use of organic fertilizer to increase their income. In addition, the application of ZA fertilizer has a significant effect but has a negative correlation on farm income so farmers should reduce the use of ZA fertilizer.

\section{REFERENCES}

Djamhari, S. (2009). Kajian Penerapan Mekanisasi Pertanian di Lahan Rawa Lebak Desa Putak - Muara Enim. Jurnal Sains Dan Teknologi Indonesia, 11(8), 157-161.

Fitriyani, L. A., \& Bangun, Y. R. (2014). Impact of Sri Organic As Community Development Program of Pt Medco E \& P Indonesia. Jurnal Manajemen \& Agribisnis, 11(3), 164-171.

Handaka, \& Prabowo, A. (2013). Anticipatory Policy on Agricultural Mechanization Development. Jurnal Analisis Kebijakan Pertanian, 11(1), 27-44.

Hanggana, S. (2018). Regulations Weakness Analysis of Farmers Group, Gapoktan, UPJA, and LKM-A in 
Order to Enhance Farmers' Income. Jurnal Analisis Kebijakan Pertanian, 15(2), 137-149.

Harnel. (2012). Kajian Teknis Dan Ekonomis Alat Tanam Bibit Padi Manual (Transplanter) Modifikasi Balai Besar Pengembangan Mekanisasi Pertanian Di Kabupaten Sijunjung, Sumatera Barat. Jurnal Pengkajian Dan Pengembangan Teknologi Pertanian, 15(1), 38-46.

Kusnadi, N., Tinaprilla, N., Susilowati, S. H., \& Purwoto, A. (2011). Analisis Efisiensi Usahatani Padi Di Beberapa Sentra Produksi Padi Di Indonesia. Jurnal Agro Ekonomi, 29(1), 25-48.

Loesasi, A. R. (2013). Pengaruh Mekanisasi Pertanian Padi Terhadap Penyerapan Tenaga Kerja di Desa Sukowiyono Kecamatan Padas Kabupaten Ngawi Ayu. Jurnal Swara Bhumi, 2(1), 268-275.

Padmanabha, I. G., Arthagama, I. D. M., \& Dibia, I. nyoman. (2014). Pengaruh Dosis Pupuk Organik dan Anorganik terhadap Hasil Padi (Oriza sativa L .) dan Sifat Kimia Tanah pada Inceptisol Kerambitan Tabanan. Jurnal Agroekoteknologi Tropika, 3(1), 41-50.
Suratiyah, K. (2008). Ilmu Usahatani. Jakarta: Penebar Swadaya.

Suratiyah, K. (2010). Dampak Teknologi Agriculture Growth Promoting Inoculant (Agpi) Pada Usahatani Padi Sawah di Kabupaten Sleman. Jurnal Agro Ekonomi, 17(1), 8190.

Takeshima, H., Nin-Pratt, A., \& Diao, X. (2013). Mechanization and agricultural technology evolution, agricultural intensification in Sub-Saharan Africa: Typology of agricultural mechanization in Nigeria. American Journal of Agricultural Economics, 95(5), 1230-1236.

Umar, S. (2014). Pengelolaan Dan Pengembangan Alsintan Untuk Mendukung Usahatani Padi di Lahan Pasang Surut. Jurnal Teknologi Pertanian, 9(1), 34-38.

Widiastuti, P. (2014). Dampak Mekanisasi Pertanian Terhadap Pendapatan Petani Padi di Kabupaten Klaten (Studi Pada UPJA Agawe Santoso Kecamatan Kalikotes). Tesis Tidak Diterbitkan, Program Pasca Sarjana Universitas Gadjah Mada. 